\title{
COMMON BEAN YIELD AS AFFECTED BY IN FURROW FILLER LIMING AND NITROGEN TOPDRESSING ${ }^{1}$
}

\author{
JOSÉ GERALDO DA SILVA², ENDERSON PETRÔNIO DE BRITO FERREIRA ${ }^{2 *}$, \\ ADRIANO STEPHAN NASCENTE ${ }^{2}$
}

\begin{abstract}
The use of filler liming in the sowing furrow can improve the chemical characteristics of the soil and, together with nitrogen fertilization, increase common bean yield. The objective of this study was to determine the effect of filler liming of the sowing furrow along with nitrogen topdressing fertilization on the yield of common bean, cultivar Pérola, irrigated by central pivot, in the Cerrado Region. The field experiments were conducted for three consecutive cropping years, in a randomized block design with four replications, in a $2 \times 4$ factorial scheme, consisting of two doses of nitrogen topdressing fertilization (zero and $60 \mathrm{~kg} \mathrm{ha}^{-1}$ of N) and four doses of filler liming application in the sowing furrow $\left(0,200,400\right.$ and $\left.600 \mathrm{~kg} \mathrm{ha}^{-1} \mathrm{of} \mathrm{CaCO}_{3}\right)$. The plant density (PD), number of pods (NP), number of grains (NG), mass of 100 grains (M100) and, grain yield (GY) were evaluated. The use of $60 \mathrm{~kg} \mathrm{ha}^{-1}$ of $\mathrm{N}$ provided greater M100 and GY. The increase of the filler liming doses in the sowing furrow led to a reduction of the NP. The filler liming dose of $200 \mathrm{~kg}^{-1} \mathrm{provided}^{-1}$ higher values of NG and M100, and when combined with the nitrogen topdressing fertilization, improved the GY of the common bean.
\end{abstract}

Keywords: Phaseolus vulgaris. Soil correction. Nitrogen fertilization. Calcium carbonate. Cerrado.

\section{EFEITO DA APLICAÇÃO DE CALCÁRIO FILLER NO SULCO DE SEMEADURA E NITROGÊNIO EM COBERTURA NA PRODUTIVIDADE DO FEIJÃO-COMUM}

\begin{abstract}
RESUMO - O uso de calcário filler no sulco de semeadura, aliada à adubação nitrogenada em cobertura, é uma prática pouco utilizada e seus efeitos sobre os atributos químicos do solo e produtividade do feijão comum necessitam ser estudados. O objetivo deste estudo foi determinar o efeito da aplicação de calcário filler no sulco de semeadura, juntamente com a adubação nitrogenada de cobertura, na produtividade do feijão-comum, cultivar Pérola, irrigado por pivô-central, cultivado no Cerrado. Os experimentos de campo foram conduzidos por três safras consecutivas, em delineamento de blocos ao acaso com quatro repetições, no esquema fatorial $2 \times 4$, sendo duas doses de nitrogênio em cobertura (zero e $60 \mathrm{~kg} \mathrm{ha}^{-1} \mathrm{de} \mathrm{N}$ ) e quatro doses de cálcario filler no

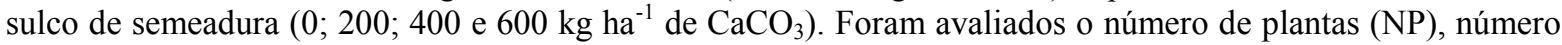
de vagens $(\mathrm{NV})$, número de grãos (NG), massa de 100 grãos (M100) e a produção de grãos (PG). $\mathrm{O}$ uso de $60 \mathrm{~kg} \mathrm{ha}^{-1}$ de $\mathrm{N}$ proporcionou maior M100 e GY. O incremento nas doses de calcário filler no sulco de semeadura proporcionou redução no NV. A aplicação de $200 \mathrm{~kg} \mathrm{ha}^{-1}$ de calcário filler proporcionou os maiores valores de NG e M100 e, quando combinada com a adubação nitrogenada em cobertura, proporcionou maior PG do feijão-comum.
\end{abstract}

Palavras-chave: Phaseolus vulgaris. Correção do solo. Adubação nitrogenada. Carbonato de cálcio. Cerrado.

\footnotetext{
${ }^{*}$ Corresponding author

${ }^{1}$ Received for publication in $11 / 24 / 2020$; accepted in $08 / 27 / 2021$

Paper of the Experimentation Research Group.

${ }^{2}$ Embrapa Arroz e Feijão, Santo Antônio de Goiás, GO, Brazil; josegeraldo.silva@embrapa.br - ORCID: 0000-0002-6817-204X, enderson.ferreira@embrapa.br - ORCID: 0000-0002-1964-1516, adriano.nascente@embrapa.br-ORCID: 0000-0002-6014-3797.
} 


\section{INTRODUCTION}

The common bean has great economic importance for Brazil. In the 2018 harvest, the cultivated area was 3.2 million hectares, with a grain production of 3.1 million tons (CNPAF, 2020). In Brazil, the crop is grown in three different cropping seasons: rainy season (September to December), dry season (January to March) and winter season (May to July). However, despite its importance, there is still low productivity, mainly in the rainy $\left(1,225 \mathrm{~kg} \mathrm{ha}^{-1}\right)$ and dry $\left(842 \mathrm{~kg} \mathrm{ha}^{-1}\right)$ seasons, due to the low use of technology (CNPAF, 2020).

The winter season can be described as more technologically intensive, characterized by a huge use of industrial products (NASCENTE et al., 2012) and normally has a higher average grain yield, with about 2,596 kg ha- ${ }^{-1}$ (CNPAF, 2020). These data indicate that the use of technology leads to significant increases in grain yield of the common bean. Among the aspects that must be improved, aiming to achieve high productivity levels, acidity correction and fertility management of the soil are crucial (CARVALHO et al., 2018; DIDA; ETISA, 2019). Thus, the adequate and balanced supply of nutrients to the common bean crop by liming and fertilizer use provides significant increases in crop productivity (KIPNGETICH; MWONGA; OJIEM, 2021).

In most grain producing areas under no-tillage system, the correction of the soil acidity has been carried out by applying lime on the soil surface, without incorporation (TIRITAN et al., 2016). With the application of lime, there is an increase in $\mathrm{pH}$ values, calcium and magnesium levels, base saturation and reduction of exchangeable aluminum levels in the soil (CAIRES et al., 2008; PAGANI; MALLARINO, 2012).

However, even in corrected soils, the application of small doses of lime (less than $1000 \mathrm{~kg} \mathrm{ha}^{-1}$ ) in the sowing furrow can provide benefits to the crop (NASCENTE; COBUCCI, 2015a). For example, the application of calcium carbonate solution in the sowing furrow in corrected soil increases the availability of phosphorus and the productivity of the common bean (NASCENTE; COBUCCI, 2015a).

Considering that in no-tillage system, limestone is applied on the soil surface, without incorporation into the soil profile, the use of filler limestone in the furrow can improve the environment for the development of crops by supplying nutrients and fast correction of soil acidity due to its high reactivity. While conventional limestone has particle sizes ranging from $50 \%<0.3 \mathrm{~mm}$ and $50 \%>0.3 \mathrm{~mm}$, with reactivity ranging from 75 to $100 \%$, filler limestone has a much finer particle size, less than
$0.30 \mathrm{~mm}$, showing reactivity greater than $100 \%$ (PRIMAVESI; PRIMAVESI, 2004).

Besides, among fertilizers, $\mathrm{N}$-fertilizers are of great importance because they provide nitrogen $(\mathrm{N})$, one of the most absorbed and most influential nutrient on crop growth (NASCENTE et al., 2017), which when applied as a topdressing after sowing can significantly affect the crop yield (SOUSA et al., 2020).

Although the combined use of filler liming in the sowing furrow and nitrogen topdressing fertilization can have a beneficial effect on the common bean yield, studies in Cerrado soils are still limited. Therefore, this work aimed at determining the effect of filler liming of the sowing furrow together with nitrogen topdressing on the yield components and grain yield of the common bean cultivar Pérola, irrigated by central pivot, in the Cerrado region.

\section{MATERIAL AND METHODS}

The experiments were carried out in the winter season of three different cropping years (2014, 2015 and 2016), in the experimental area of Embrapa Arroz e Feijão, located in the municipality of Santo Antonio de Goiás-GO, under the coordinates $16^{\circ} 28^{\circ} 00^{\prime \prime} \mathrm{S}, 49^{\circ} 17^{\prime} 00^{\prime \prime} \mathrm{O}$ and altitude of $823 \mathrm{~m}$. According to Köppen's classification the climate of the region is an Aw, tropical savanna, with dry season in winter and rainy in summer. The annual rainfall varies from 1.500 to $1.700 \mathrm{~mm}$. The mean annual temperature is $22.7^{\circ} \mathrm{C}$, varying from $14.2{ }^{\circ} \mathrm{C}$ in the winter and $34.8{ }^{\circ} \mathrm{C}$ in the summer. Mean temperatures, rainfall distribution and irrigation events during the three experimental periods are presented in Figure 1.

The soil of the experimental areas is classified as an Oxisol (SOIL SURVEY STAFF, 2014). During the previous five years the experimental area was cropped with maize/soybean in the summer and with common bean in the winter under no-tillage. Before experiment settlement, 20 soil subsamples were taken at $0-20 \mathrm{~cm}$ depth to evaluate soil chemical properties. Chemical analysis followed basic procedures (DONAGENA et al., 2011). Before being analyzed, soil samples were dried $\left(60{ }^{\circ} \mathrm{C}\right.$ for $48 \mathrm{~h}$ ) and sieved (2-mm). Soil $\mathrm{pH}$ was determined in $0.01 \mathrm{M} \mathrm{CaCl}_{2}$ (1:2.5; soil/solution), after agitation for $1 \mathrm{~h}$. Exchangeable $\mathrm{Ca}$ and $\mathrm{Mg}$ were determined in the extract obtained with $1 \mathrm{~mol} \mathrm{~L}^{-1} \mathrm{KCl}(1: 10$; soil/solution) after agitation for $10 \mathrm{~min}$. $\mathrm{P}$ and $\mathrm{K}$ contents were evaluated in the Mehlich-1 $\left(0.05 \mathrm{~mol} \mathrm{~L}^{-1} \mathrm{HCl}+0.0125 \mathrm{~mol} \mathrm{~L}^{-1} \mathrm{H}_{2} \mathrm{SO}_{4}\right)$ extract (1:10; soil/solution) after agitation for $10 \mathrm{~min}$. Concentrations of $\mathrm{Ca}$ and $\mathrm{Mg}$ were determined in an atomic absorption spectrophotometer, $\mathrm{K}$ in a flame 
photometer and $\mathrm{P}$ by colorimetry, using the molybdenum-blue method and ascorbic acid as reducing agent. Organic matter was determined by
Walkley \& Black method. Soil characteristics before sowing at each site are shown in Table 1.
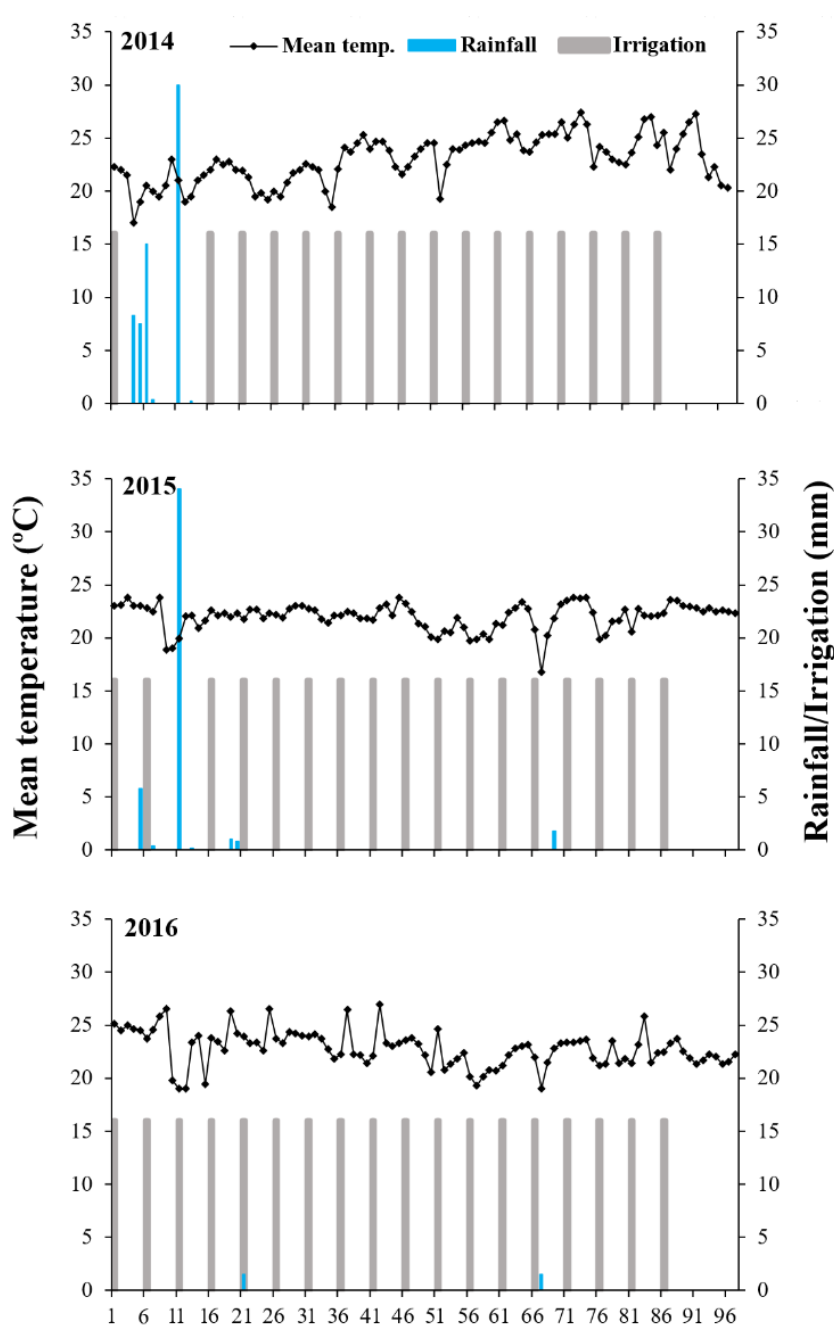

Days after sowing

Figure 1. Mean temperatures, rainfall distribution and irrigation events at Santo Antônio de Goiás (Cerrado region, Brazil) during crop growing periods of the three experiments.

Table 1. Soil chemical analysis at different cropping years before field experiment implementation.

\begin{tabular}{|c|c|c|c|c|c|c|}
\hline \multirow[b]{2}{*}{ Cropping years } & $\mathrm{pH}$ & $\mathrm{Ca}$ & $\mathrm{Mg}$ & $P$ & $\mathrm{~K}$ & \multirow{2}{*}{$\frac{\mathrm{SOM}^{1}}{\mathrm{~g} \mathrm{~kg}^{-1}}$} \\
\hline & in $\mathrm{H}_{2} \mathrm{O}$ & \multicolumn{2}{|c|}{$\mathrm{mmol}_{\mathrm{c}} \mathrm{dm}^{-3}$} & \multicolumn{2}{|c|}{$\mathrm{mg} \mathrm{kg}^{-1}$} & \\
\hline 2014 & 5.7 & 16.7 & 13.4 & 18.1 & 125 & 26.6 \\
\hline 2015 & 5.4 & 26.0 & 10.1 & 12.4 & 92 & 34.3 \\
\hline 2016 & 6.0 & 15.1 & 12.7 & 13.0 & 171 & 32.7 \\
\hline
\end{tabular}

${ }^{1}$ Soil organic matter.

All experiments were assigned to a completely randomized block design, in a $2 \times 4$ factorial scheme, with four replications. The treatments consisted of the combination of two doses of nitrogen $(\mathrm{N})$ (zero or $60 \mathrm{~kg} \mathrm{ha}^{-1}$ of $\mathrm{N}$ ) and four doses of filler limestone applied to the sowing furrow $\left(0 ; 200 ; 400\right.$ and $\left.600 \mathrm{~kg} \mathrm{ha}^{-1}\right)$. The plots were composed of five rows with five meters in length and $0.45 \mathrm{~m}$ between rows. Plot size was $11.25 \mathrm{~m}^{2}$ ( 5 rows $\mathrm{X} 5 \mathrm{~m} \mathrm{X} 0.45 \mathrm{~m}$ ) and the plots were separated by rows of at least $0.9 \mathrm{~m}$ to prevent contamination by superficial run-off containing 
fertilizer. The useful area had $5.4 \mathrm{~m}^{2}$, composed by the three central rows, discarding $0.50 \mathrm{~m}$ from each end.

The fertilization in the sowing furrow was $320 \mathrm{~kg} \mathrm{ha}{ }^{-1}$ of the formulated $5-30-15$ $\left(\mathrm{N}-\mathrm{P}_{2} \mathrm{O}_{5}-\mathrm{K}_{2} \mathrm{O}\right)$. The filler limestone had $30 \% \mathrm{CaO}$ and was mixed with the fertilizer. The volume was completed with sand to be applied at a dose of $920 \mathrm{~kg} \mathrm{ha}^{-1}$ in the sowing furrow using a seederfertilizer machine with five sowing lines, spaced $0.45 \mathrm{~m}$ apart, and with double-sided fertilizer furrow and furrow seeder. The machine was set to operate at a speed of $4 \mathrm{~km} \mathrm{~h}^{-1}$. Fifteen common bean seeds of the cultivar Pérola were distributed per meter. Urea was used as the $\mathrm{N}$ source and, was applied as a topdressing at the $\mathrm{V} 4$ vegetative stage (third trifoliolate leaf).

At each year of experimentation, trials were installed on the first half of June in areas with central pivot irrigation. Irrigation management was done according to the crop requirements with irrigations at each 2 days until germination and, at each 4 days afterwards, totaling an application of $325 \mathrm{~mm}$.

Weed plants can hinder crop development by competing for natural resources such as water and nutrients. Its control was done by applying Fomesafen $\left(1.0 \mathrm{~L} \mathrm{ha}^{-1}\right)$ at $\mathrm{V}_{2}$ stage and Fluasifop-pbutil $\left(1.0 \mathrm{~L} \mathrm{ha}^{-1}\right)$ at $\mathrm{V}_{3}$ stage Fungicides Chlorothalonil, 900 g a.i. ha ${ }^{-1}$ (against anthracnose $=$ Colletotrichum lindemuthianum), thiophanate-methyl, $450 \mathrm{~g}$ a.i. ha ${ }^{-1}$ (against angular leaf spot=Phaeoisariopsis griseola) and Trifloxystrobin+Propiconazole, $130 \mathrm{~g}$ a.i. $\mathrm{ha}^{-1}$ (against powdery mildew=Erysiphe polygoni) were applied after flowering. Insecticides (thiamethoxam, $0.1 \mathrm{~kg} \mathrm{ha}^{-1}$; Imidacloprid, $0.5 \mathrm{~L} \mathrm{ha}^{-1}$ and Chlorpyrifos chlorpyrifos, $1.0 \mathrm{~L} \mathrm{ha}^{-1}$ ) were applied against Bemisia tabaci, Heliothis zea and Etiella zinckenella, respectively.

At the R9 phenological stage, the plant density (PD) was determined by counting the number of plants per meter. For the yield components evaluation 10 plants were randomly collected per plot to determine the number of pods (NP) per plant and the number of grains (NG) per pod. From each sample 100 grains were weighted to determine the mass of 100 grains (M100). To determine grain yield (GY), the useful plot was collected. The grains were weighed, and the moisture corrected to $13 \%$ and GY expressed in $\mathrm{kg} \mathrm{ha}^{-1}$.

The data obtained in the experiments were grouped and the analysis by experiment group was performed. When the differences were significant ( $p<0.05$, teste " $t$ "), the results of each cropping year were analyzed separately. The data was submitted to analysis of variance and upon confirmation of a statistically significant value in the $F$ test $(p \leq 0.05)$, regression analysis at 5\% significance was applied for the filler liming doses, since $\mathrm{N}$ application was evaluated only for 0 and $60 \mathrm{~kg} \mathrm{ha}^{-1}$. Statistical analysis was performed using the software Sisvar (FERREIRA, 2011).

\section{RESULTS AND DISCUSSION}

The evaluation of the effects of filler liming doses and the topdressing applications of $\mathrm{N}$ on common bean revealed that the plant density (PD), the number of pods per plant (NP), the number of grains (NG), the mass of 100 grains (M100) and the grain yield (GY) differed between the evaluated cropping years (Table 2). Cropping years 2014 and 2015 had the highest grain yield and differed from 2016 cropping year. This was because 2016 witnessed the lowest pod numbers and mass of 100 grains. According to Fageria and Santos (2008), number of pods per plant, number of grains per pod and mass of 100 grains are the main yield components of the common bean and directly affect grain yield.

Significant effects of $\mathrm{N}$ doses and filler liming doses were observed for some of the evaluated parameters. However, none significant interaction was observed between $\mathrm{N}$ and filler liming doses (Table 3).

Table 2. Joint analysis of the experiments carried out in the 2014, 2015 and 2016 cropping years, with topdressing $\mathrm{N}$-fertilization and filler liming of the sowing furrow. Plant density $\left(\mathrm{PD}-\mathrm{n}^{\mathrm{o}} \mathrm{m}^{-1}\right)$, number of pods $\left(\mathrm{NP}-\mathrm{n}^{\mathrm{o}}\right.$ plant $\left.{ }^{-1}\right)$, number of grains (NG- $\mathrm{n}^{\mathrm{o}}$ pod $\left.^{-1}\right)$, mass of 100 grains $(\mathrm{M} 100-\mathrm{g})$ and grain yield $\left(\mathrm{GY}-\mathrm{kg} \mathrm{ha}^{-1}\right)$ of common bean.

\begin{tabular}{cccccc}
\hline Cropping year $(\mathrm{CY})$ & PD & NP & NG & M100 & GY \\
\hline 2014 & $8.78 \mathrm{c}$ & $12.92 \mathrm{~b}$ & $3.90 \mathrm{~b}$ & $23,43 \mathrm{~b}$ & $2,235.59 \mathrm{a}$ \\
2015 & $10.15 \mathrm{~b}$ & $14.07 \mathrm{a}$ & $3,30 \mathrm{c}$ & $28.95 \mathrm{a}$ & $2,371.22 \mathrm{a}$ \\
2016 & $11.70 \mathrm{a}$ & $11.76 \mathrm{c}$ & $4.52 \mathrm{a}$ & $20.09 \mathrm{c}$ & $1,694.88 \mathrm{~b}$ \\
$F_{C Y}$ & $71.02^{* *}$ & $14.00^{* *}$ & $116.77^{* *}$ & $645.97^{* *}$ & $52.15^{* *}$ \\
\hline $\mathrm{CV}(\%)$ & 9.62 & 13.49 & 8.18 & 4.12 & 13.34 \\
\hline
\end{tabular}

$C V=$ Coefficient of variation; ${ }^{*}$ significant $\left(p<0.05\right.$, " $F "$ test), ${ }^{* *}$ significant $\left(p<0.01\right.$, " $F$ " test), ${ }^{\text {ns }}$ non significant $(p>0.05$, " $F$ " test). Mean values followed by different letters within each column are statistically different ( $p<0.05$, teste " $t$ "). 
Table 3. F values and its significance for plant density $\left(\mathrm{PD}-\mathrm{n}^{\mathrm{o}} \mathrm{m}^{-1}\right)$, number of pods $\left(\mathrm{NP}-\mathrm{n}^{\mathrm{o}}\right.$ plant $\left.\mathrm{t}^{-1}\right)$, number of grains $\left(\mathrm{NG}-\mathrm{n}^{\mathrm{o}} \operatorname{pod}^{-1}\right.$ ), mass of 100 grains (M100- $\mathrm{g}$ ) and grain yield (GY- $\mathrm{kg} \mathrm{ha}^{-1}$ ) of the common bean as affected by filler liming and topdressing application of $\mathrm{N}$.

\begin{tabular}{|c|c|c|c|c|c|c|c|c|c|}
\hline \multirow{2}{*}{ Factors } & \multicolumn{3}{|c|}{ PD } & \multicolumn{3}{|c|}{ NP } & \multicolumn{3}{|c|}{ NG } \\
\hline & 2014 & 2015 & 2016 & 2014 & 2015 & 2016 & 2014 & 2015 & 2016 \\
\hline$N$ doses $(N)$ & $0.82^{\mathrm{ns}}$ & $0.93^{\mathrm{ns}}$ & $3.34^{\mathrm{ns}}$ & $0.18^{\mathrm{ns}}$ & $0.01^{\mathrm{ns}}$ & $0.64^{\mathrm{ns}}$ & $3.38^{\mathrm{ns}}$ & $4.76^{*}$ & $0.36^{\mathrm{ns}}$ \\
\hline Filler doses $(F)$ & $0.44^{\mathrm{ns}}$ & $3.32^{* *}$ & $52.31^{* *}$ & $2.93^{*}$ & $0.59^{\mathrm{ns}}$ & $7.90 * *$ & $2.33^{\mathrm{ns}}$ & $0.58^{\mathrm{ns}}$ & $7.44 * *$ \\
\hline Interaction $(\mathrm{NxF})$ & $0.66^{\mathrm{ns}}$ & $1,84^{\mathrm{ns}}$ & $0.48^{\mathrm{ns}}$ & $1.5^{\mathrm{ns}}$ & $2.76^{\mathrm{ns}}$ & $1.34^{\mathrm{ns}}$ & $3.57^{\mathrm{ns}}$ & $1.69^{\mathrm{ns}}$ & $3.17^{\mathrm{ns}}$ \\
\hline $\mathrm{CV}(\%)$ & 5.58 & 11.39 & 9.46 & 10.92 & 15.60 & 13.90 & 6.64 & 10.31 & 7.19 \\
\hline \multirow{2}{*}{ Factors } & \multicolumn{4}{|c|}{ M100 } & & \multicolumn{4}{|c|}{ GY } \\
\hline & & 2014 & 2015 & 2016 & & 2014 & & & 2016 \\
\hline$N \operatorname{doses}(N)$ & & $7.16^{*}$ & $0.03^{\mathrm{ns}}$ & $4.28^{\mathrm{ns}}$ & & $11.29^{* *}$ & & & $52.83^{* *}$ \\
\hline Filler doses $(F)$ & & $5.80^{* *}$ & $3.13^{*}$ & $4.51^{*}$ & & $3.52^{*}$ & & & $15.32^{* *}$ \\
\hline Interaction $(\mathrm{N} x \mathrm{~F})$ & & $3.80^{\mathrm{ns}}$ & $0.23^{\mathrm{ns}}$ & $7.45^{\mathrm{ns}}$ & & $2.38^{\mathrm{ns}}$ & & & $1.95^{\mathrm{ns}}$ \\
\hline $\mathrm{CV}(\%)$ & & 3.83 & 4.14 & 3.31 & & 14.51 & & & 11.74 \\
\hline
\end{tabular}

$\mathrm{CV}=$ Coefficient of variation; " significant $\left(\mathrm{p} \leq 0.05\right.$, "F" test), ${ }^{* *}$ significant $\left(\mathrm{p} \leq 0.01\right.$, " $\mathrm{F}$ " test), ${ }^{\text {ns }}$ non significant $(\mathrm{p} \geq 0.05$, , $\mathrm{F}$ " test).

The topdressing application of $60 \mathrm{~kg} \mathrm{ha}^{-1}$ of $\mathrm{N}$ resulted in NG value of 3.17, decreasing the NG by about $8 \%$ as compared to the non-addition of nitrogen. However, the topdressing application of $60 \mathrm{~kg} \mathrm{ha}^{-1}$ of $\mathrm{N}$ increased the M100 in 2014 to $26.86 \mathrm{~g}$ and the GY in 2014 to $2428.31 \mathrm{~kg} \mathrm{ha}^{-1}$ and in 2015 to $1950.44 \mathrm{~kg} \mathrm{ha}^{-1}$, in comparison to the zero dose, representing an increase of about $3.7 \%, 18.9 \%$ and $35 \%$, respectively. Nitrogen is one of the most required nutrients by the common bean and its proper supply significantly affects production components and grain yield, since nitrogen is a constituent of several molecules that play important metabolic functions in plants (WANG et al., 2014). Additionally, Sorato; Perez and Fernandes (2014) and Lacerda; Nascente and Pereira (2019) also reported that increasing $\mathrm{N}$ rates provided increases in mass of 100 grains and in the grain yield of common bean.

Filler liming doses resulted in a significant effect on PD in 2015 and 2016, on NP in 2014 and 2016, on NG in 2016, on M100 in 2014, 2015 and 2016 and, on GY in 2014 and 2016 (Table 3). The regression analysis of the filler liming doses revealed a quadratic effect on the evaluated parameters (Figures 2, 3, 4, 5 and 6). Regarding PD, the adjustment coefficients $\left(\mathrm{R}^{2}\right)$ were $76 \%$ and $54 \%$ in 2015 and 2016, respectively, with the PD values being reduced as the filler liming doses increased (Figure 2). In 2015 the largest PD was observed without the addition of filler liming, while in 2016, the largest PD was observed with the addition of $200 \mathrm{~kg} \mathrm{ha}^{-1}$ of filler liming (Figure 2).

The increase in the doses of filler liming can lead to changes in $\mathrm{pH}$ values in the rhizosphere, since the application of lime, even superficially, increases the soil pH (TOFFOLLI et al., 2014). Increased liming levels, which increase $\mathrm{pH}$, can increase molybdenum availability (FAGERIA; BALIGAR; JONES, 2011), reduce the net photosynthesis rate, stomatal conductance and transpiration rate (QIN et al., 2017). Therefore, the higher filler liming rates evaluated in our study can be related to the reduction of the PD, although Silva et al. (2012) did not observe effects of conventional limestone doses on PD. However, the application of filler liming in furrow is a very little studied issue, with limited availability of published works.

The increase in filler liming doses in the sowing furrow increased the number of pods (NP), with a higher NP obtained at the doses of 600 and $400 \mathrm{~kg} \mathrm{ha}^{-1}$ in 2014 and 2016, respectively (Figure 3). Although NP tended to increase as a resultant effect of increasing the filler liming dose, in 2016 a decrease in NP was observed in the highest dose of filler liming, corresponding to $600 \mathrm{~kg} \mathrm{ha}^{-1}$. Nascente and Cobucci (2015b) also reported a reduction in the number of pods per plant due to the increase in limestone doses, which could be a result of the decrease in the availability of phosphorus in the soil that occurs at high $\mathrm{pH}$ levels (PENN; CAMBERATO, 2019.). 


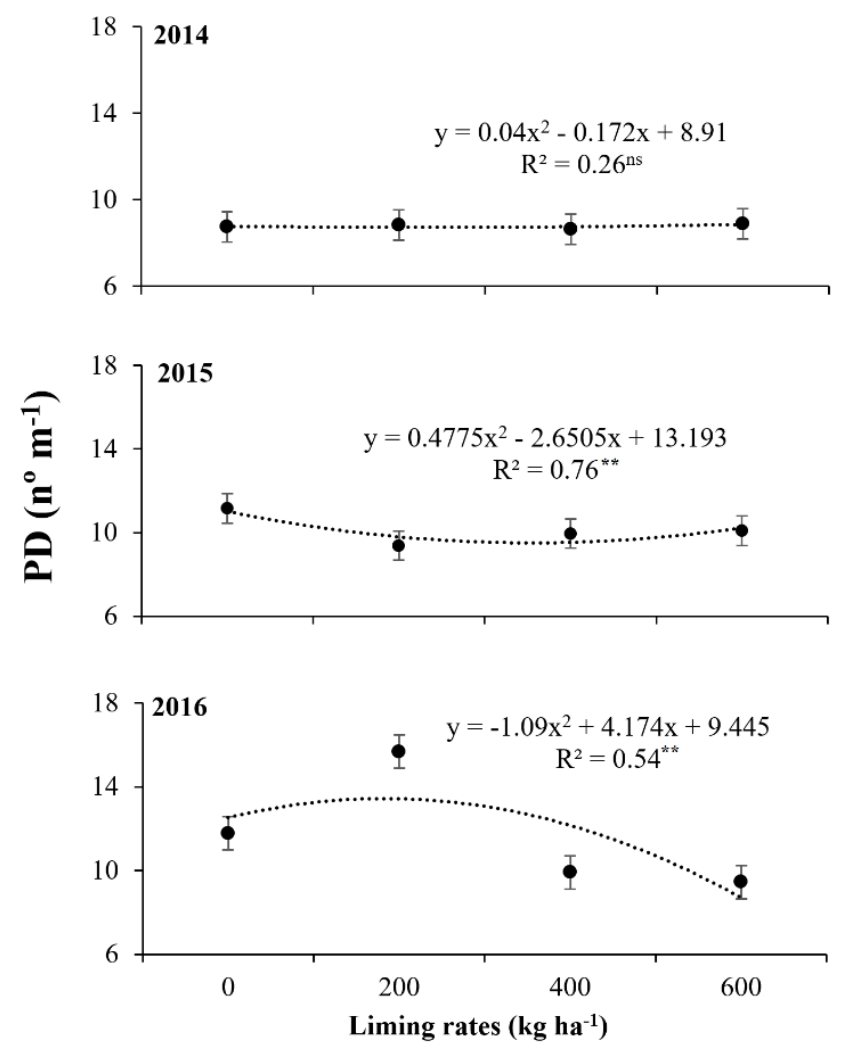

Figure 2. Regression analysis of filler liming doses effects on the plant density (PD) of the common bean in 2014, 2015 and 2016 cropping years.

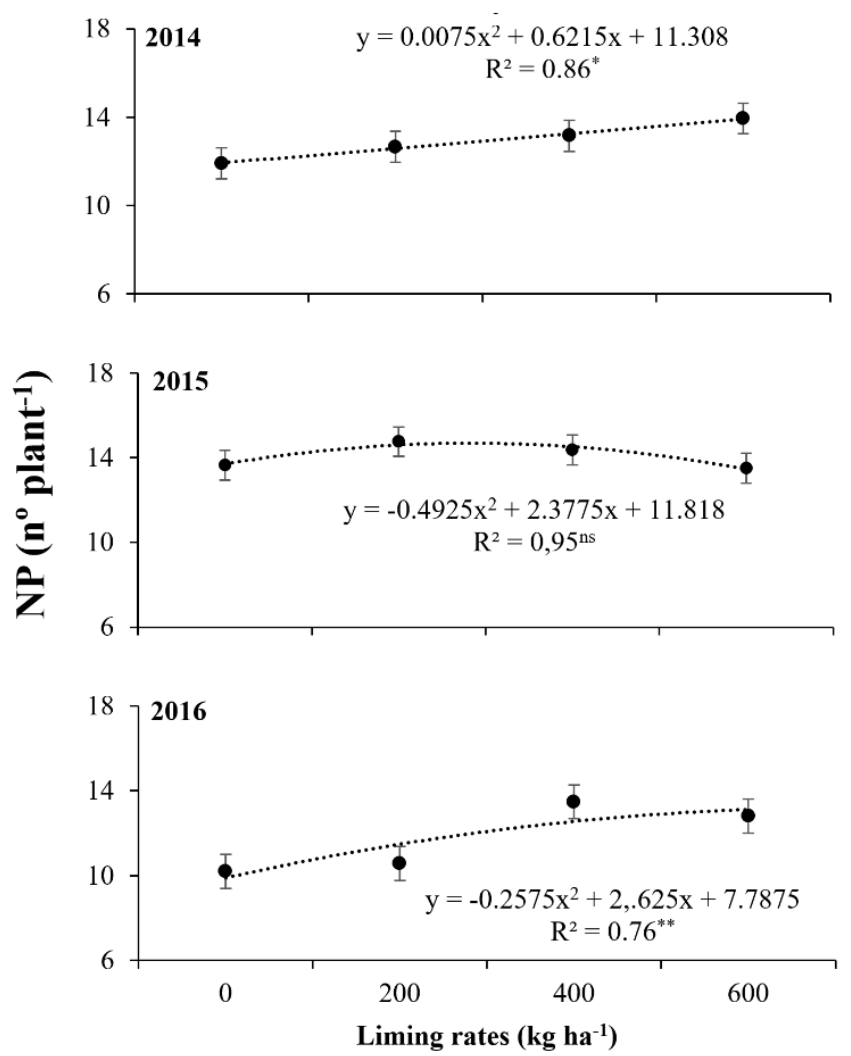

Figure 3. Regression analysis of filler liming doses effects on the number of pods (NP) of the common bean in 2014, 2015 and 2016 cropping years. 
In spite of NP and NG showing a high correlation coefficient (DALCHIAVON; CARVALHO, 2012; PERINI et al., 2012), in our study the NG was not affected in the same manner as NP. The effects of filler liming doses on NG showed inconclusive results, with significant effect only in one (2016) of the three evaluated cropping years (Table 2), where greater NG has been observed with the use of 200 and $600 \mathrm{~kg} \mathrm{ha}^{-1}$ of filler liming, as compared to zero and $400 \mathrm{~kg} \mathrm{ha}^{-1}$ (Figure 4).

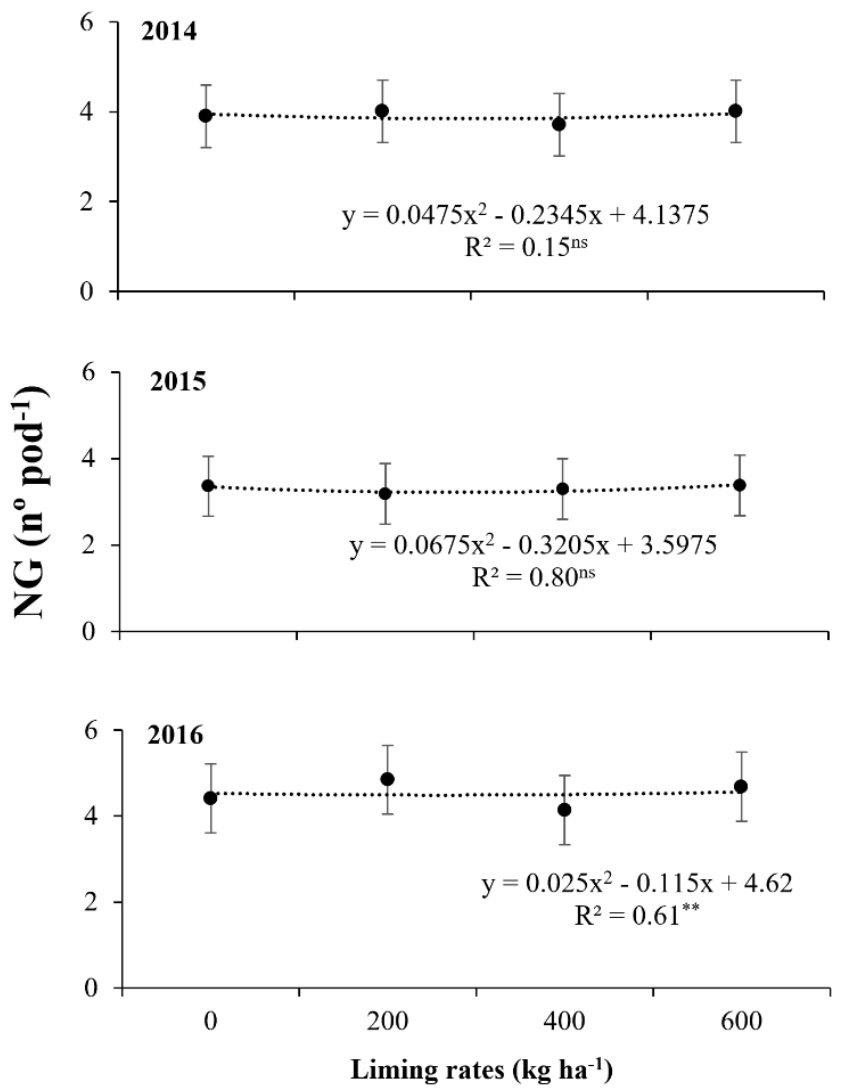

Figure 4. Regression analysis of filler liming doses effects on the number of grains (NG) of the common bean in 2014, 2015 and 2016 cropping years.

The mass of 100 grains (M100) varied significantly depending on the cropping year, with values inversely proportional to those observed for the $\mathrm{NG}$, where the highest and lowest values of M100, observed in the 2015 and 2016 cropping years, respectively, corresponded to the smallest and highest NG values (Figure 4). According to Barili et al. (2011), the parameters grain mass and number of grains have an inverse correlation. Regarding the effect of the filler liming doses, the regression analysis revealed that the highest values of M100 were observed with the doses of 600,200 and $400 \mathrm{~kg} \mathrm{ha}^{-1}$, in the 2014, 2015 and 2016 cropping years, respectively (Figure 5).

In 2014 and 2015 cropping years the grain yield (GY) values were higher than those obtained in 2016 (Table 2). However, significant effects of the filler liming doses were only observed in the cropping years 2014 and 2016 (Figure 6). The dose of $200 \mathrm{~kg} \mathrm{ha}^{-1}$ of filler liming resulted in the highest GY, with subsequent decreases after this dose. According to Fageria, Baligar and Jones (2011), at high filler liming doses, a reduction in the availability of phosphorus and micronutrients occurs, leading to the decrease of the GY, since these nutrients can become unavailable to plants due to the increase in $\mathrm{pH}$ in the root region, as a result of filler limestone application in the sowing furrow.

Although a tendency to reduce GY was observed at filler liming doses greater than $200 \mathrm{~kg} \mathrm{ha}^{-1}$, it was found that in the two cropping years in which the study was conducted on soils with lower $\mathrm{pH}$ values $(2014=5.7$ and $2015=5.4)$ responses in the GY of common bean to filler liming were observed. These results indicate that, even in soils with adequate $\mathrm{pH}$ values, the application of small doses of filler limestone in the sowing furrow can provide significant increases in the grain yield of the crop (NASCENTE; COBUCCI, 2015a), since the use of lime provides better conditions for plant development (FAGERIA; BALIGAR; JONES, 2011; FAGERIA; NASCENTE, 2014). 

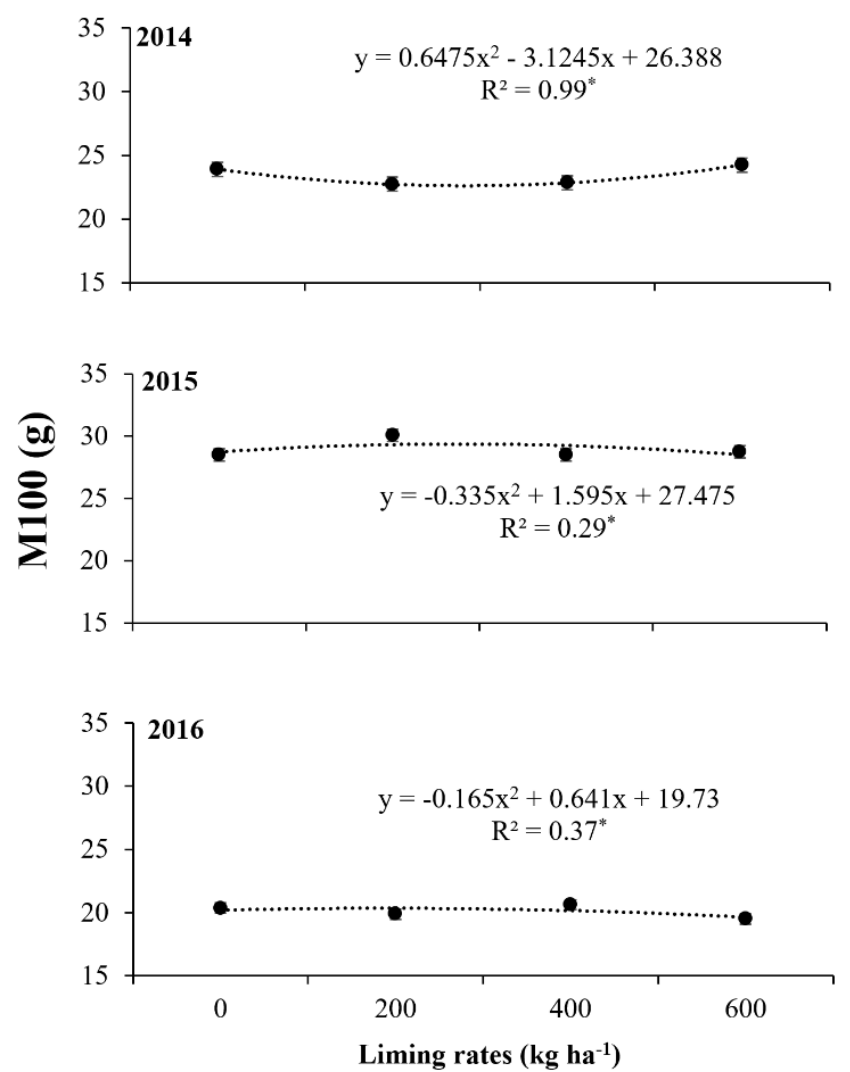

Figure 5. Regression analysis of filler liming doses effects on the mass of 100 grains (M100) of the common bean in 2014, 2015 and 2016 cropping years.
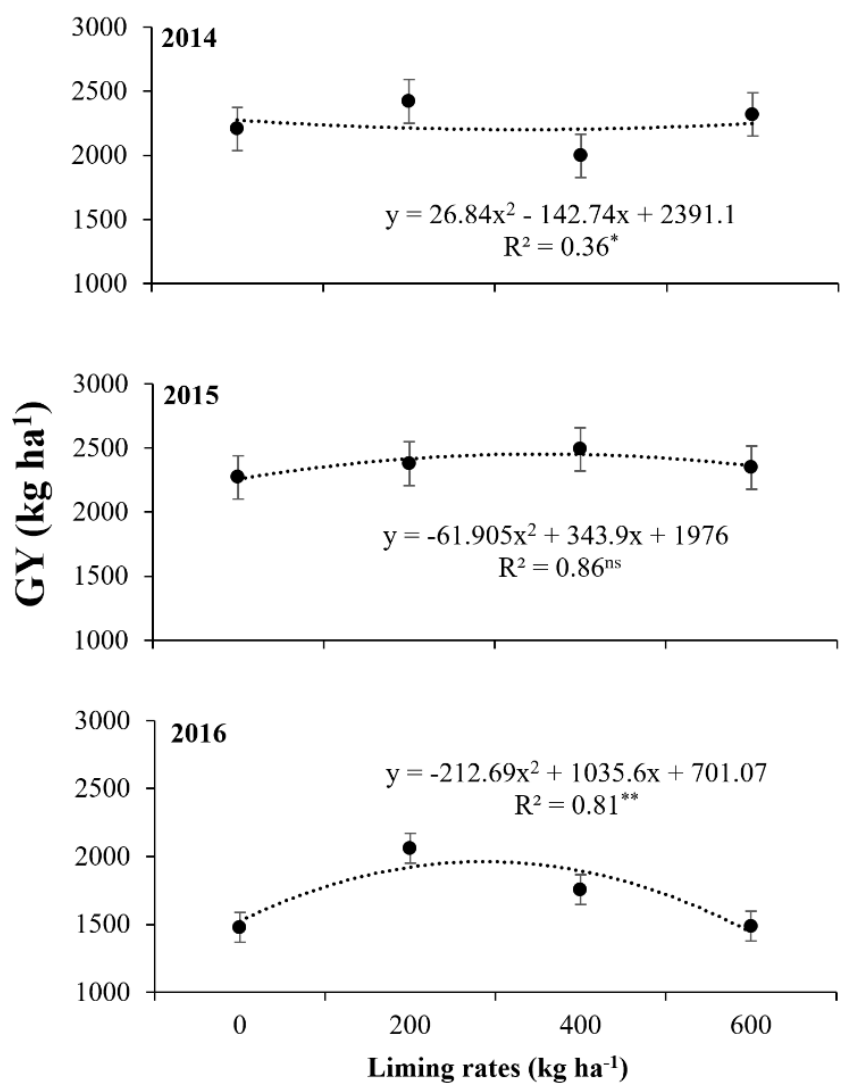

Figure 6. Regression analysis of filler liming doses effects on the grain yield (GY) of the common bean in 2014, 2015 and 2016 cropping years. 
However, these responses to filler limestone use were not observed all over the evaluated parameters, nor all through the cropping years. Besides, interactions between filler liming and $\mathrm{N}$ doses were not observed. Thus, long term experiments under field conditions are needed for a better understanding of the filler liming and $\mathrm{N}$ application on the agronomical performance of the common bean.

\section{CONCLUSIONS}

The $\mathrm{N}$ and filler limestone application influenced the yield components and grain yield of the common bean cultivar, but there was no interaction among $\mathrm{N}$ and filler limestone application. $\mathrm{N}$ application increased the number of grains, the mass of 100 grains and the grain yield of the common bean. The application of $400 \mathrm{~kg} \mathrm{ha}^{-1}$ of filler limestone increased the number of pods, while that of $200 \mathrm{~kg} \mathrm{ha}^{-1}$ increased the pod density, the number of grains, the mass of 100 grains and the grain yield of the common bean.

\section{ACKNOWLEDGEMENTS}

The authors thank Embrapa Rice and Beans for funding this study; CNPq (Brazilian Council for Scientific and Technological Development) for granting research productivity scholarships to Enderson P. B. Ferreira (grant number 313827/20206) and to Adriano S. Nascente (grant number 301064/2019-9); To Mr. Princewill C. Asobia for the grammar review of the manuscript.

\section{REFERENCES}

BARILI, L. D. et al. Correlação fenotípica entre componentes do rendimento de grãos de feijão comum (Phaseolus vulgaris L.). Semina: Ciências Agrárias, 32: 1263-1274, 2011.

CAIRES, E. F. et al. Effect of soil acidity amelioration by surface liming on no-till corn, soybean and wheat root growth and yield. European Journal of Agronomy, 28: 57-64, 2008.

CARVALHO et al. Phosphorus and potassium fertilization increase common bean grain yield in Mozambique. Revista Brasileira de Engenharia Agrícola e Ambiental, 22: 308-314, 2018.

CNPAF - Centro Nacional de Pesquisa de Arroz e Feijão. Dados de conjuntura da produção de feijão-comum (Phaseolus vulgaris L) e caupi
(Vigna unguiculata (L.) Walp) no Brasil (19852018). Disponível em: https:// www.cnpaf.embrapa.br/socioeconomia/index.htm. Acesso em: 24 de set. 2020.

DALCHIAVON, F. C.; CARVALHO, M. P. Correlação linear e espacial dos componentes de produção e produtividade da soja. Semina: Ciências Agrárias, 33: 541-552, 2012.

DIDA, G.; ETISA, D. Effect of Lime and Compost Application on the growth and yield of Common Bean (Phaseolus vulgaris L.): A Review. Advances in Oceanography \& Marine Biology, 1: 1-9, 2019.

DONAGENA, G. K. et al. Manual de métodos de análise de solo. 2. ed. Rio de Janeiro, RJ: Embrapa Solos, 2011. 212 p.

FAGERIA N. K.; NASCENTE, A. S. Management of Soil Acidity of South American Soils for Sustainable Crop Production. Advances in Agronomy, 128: 221-275, 2014.

FAGERIA, N. K.; BALIGAR, V. C.; JONES, C. A Growth and mineral nutrition of field crops. Boca Raton, CRC Press. 2011. 586 p.

FAGERIA, N. K.; SANTOS, A. B. Yield physiology of dry bean. Journal of Plant Nutrition, 31: 9831004, 2008.

FERREIRA, D. F. Sisvar: A computer statistical analysis system. Ciencia e Agrotecnologia, 35: 1039-1042, 2011.

KIPNGETICH S. C.; MWONGA, S. M.; OJIEM, J. $\mathrm{O}$. The effect of multi-component fertilizer and lime application on yield of common bean in Western Kenya. African Journal of Agricultural Research, 17: 112-117, 2021.

LACERDA, M. C.; NASCENTE, A. S.; PEREIRA, E. T. L. Adubação nitrogenada afeta a produtividade e a qualidade comercial de grãos do feijoeiro em sistema plantio direto. Revista de Ciências Agrárias, 42: 369-378, 2019.

NASCENTE, A. S. et al. Fertilization of common bean cultivars in tropical lowlands. Pesquisa Agropecuária Tropical, 42: 407-415. 2012.

NASCENTE, A. S; COBUCCI, T. Soil phosphorus availability and dry bean yield as affected by the application of liquid calcium carbonate micron particles on the furrow. African Journal of Agricultural Research, 10: 1840-1851, 2015a.

NASCENTE, A. S; COBUCCI, T. Calcário na forma 
de micropartículas aplicado no sulco de semeadura aumenta produtividade do feijoeiro. Revista Ceres, 62: 597-606, 2015b.

NASCENTE, A. S. et al. Nitrogen management effects on soil mineral nitrogen, plant nutrition and yield of super early of super cycle common bean genotypes. Acta Scientiarum: Agronomy, 39: 369$378,2017$.

PAGANI, A.; MALLARINO, A. P. Soil pH and crop grain yield as affected by the source and dose of lime. Soil Science Society of America Journal, 76: 1877-1886, 2012.

PENN, C. J.; CAMBERATO, J. J. A Critical Review on Soil Chemical Processes that Control How Soil $\mathrm{pH}$ Affects Phosphorus Availability to Plants. Agriculture, 9: 1-18, 2019.

PERINI, L. J. et al. Componentes da produção em cultivares de soja com crescimento determinado e indeterminado. Semina: Ciências Agrárias, 33: 2531-2544, 2012.

PRIMAVESI, A. C.; PRIMAVESI, O. Características de corretivos agrícolas. 1 ed. São Carlos, SP: Embrapa Pecuária Sudeste, 2004. 28 p. (Documentos 37)

QIN, S. et al. Effect of molybdenum levels on photosynthetic characteristics, yield and seed quality of two oilseed rape (Brassica napus L.) cultivars. Soil Science and Plant Nutrition, 63: 137-144, 2017.

SILVA, T. R. B. et al. Resposta de cultivares de feijoeiro comum à calagem superficial em semeadura direta. Semina: Ciências Agrárias, 33: 1281-1290, 2012.

SOIL SURVEY STAFF. Keys to Soil Taxonomy, 12th ed. USDA-Natural Resources Conservation Service, Washington, DC, 2014.

SORATTO, R. P.; PEREZ, A. A. G.; FERNANDES, A. M. Age of no-till system and nitrogen management on common bean nutrition and yield. Agronomy Journal, 106: 809-820, 2014.

SOUSA, M. A. et al. Productivity and Economics of Inoculated Common Bean as Affected by Nitrogen Application at Different Phenological Phases. Journal of Soil Science and Plant Nutrition, 20: 1848-1858, 2020.

TIRITAN, C. S. et al. Tillage system and lime application in a tropical region: Soil chemical fertility and corn yield in succession to degraded pastures. Soil and Tillage Research, 155: 437-447, 2016.

TOFFOLLI, L. C. B. et al. Application of limestone forms and doses for alfalfa in no-tillage system. Revista Ciência Agronômica, 45: 906-913, 2014.

WANG, M. et al. Chapter One - New Insight into the Strategy for Nitrogen Metabolism in Plant Cells. International Review of Cell and Molecular Biology, 310: 1-37, 2014.

This work is licensed under a Creative Commons Attribution-CC-BY https://creativecommons.org/licenses/by/4.0/ 